\title{
URBAN SPRAWL ASSESSMENT USING TIME-SERIES LULC AND NDVI VARIATION: A CASE STUDY OF SEPANG, MALAYSIA
}

\author{
YASIN, M. Y.* - YUSOF, M. M. - NOOR, N. M. \\ Department of Geography, Faculty of Arts and Social Sciences, University of Malaya \\ 50603 Kuala Lumpur, Malaysia \\ *Corresponding author \\ e-mail: yazrinyasin@gmail.com
}

(Received 26 ${ }^{\text {th }}$ Dec 2018; accepted 6 ${ }^{\text {th }}$ Mar 2019)

\begin{abstract}
Rapid urbanization that caused urban sprawl is a major worldwide concern. In this study an assessment of urban sprawl was carried out based on Land Use Land Cover (LULC), Normalized Difference Vegetation Index (NDVI) and Normalized Difference Built-up Index (NDBI) variation in Sepang, Malaysia. The land cover classification consisted of Built-up Area (BUA), Vegetation Area (VA), Open Space Area (OSA), and Water Bodies (WB) from 1990 to 2018. Supervised classification based on maximum likelihood techniques were used to identify the land use classes. Based on the analysis of LULC, the majority of VA (i.e. forest field) was transformed into OSA and gradually the land was converted into BUA. Observation within 25 years, supported by NDVI and NDBI has discovered a consistent increase of BUA while contrastingly a decline of VA, while WB and OSA are suspected to have inconsistently varying highs and lows. This study has demonstrated that urban sprawl caused by rapid urbanization has not favour the population. Without proper planning and growth control, urban sprawl in Sepang would have undesirable consequences to the quality of life and the environment. Therefore, comprehensive land use and progressive environmental change can serve as prognostic measures to mitigate urban sprawl, and to achieve sustainable urbanization and to carry out effective planning and decision making.
\end{abstract}

Keywords: urban sprawl, land use land cover, normalized difference vegetation index, normalized difference built-up index

\section{Introduction}

Urban sprawl occurs on a micro basis in almost every major cities in the world in response to increased wealth and growing dependence on private transportation (Burchell et al., 2002). Population, resources and productive activity are highly and increasingly concentrated in cities, thus require comprehensive understanding especially in the context of demographic, geographic and economic. In regard to urban sprawl, it is a global phenomenon but it is always viewed in different ways on how and why it was resulted (Barnes et al., 2002). In Eastern Europe, urban sprawl was considered as an outcome of post-socialist of autocratic transformation into liberalization of economic and social well-being (Bussauw, 2012; Nuissl and Rink, 2005). In the USA, early spatial form of sprawl occurred after World War II because of the perception that the new suburbs are safer, more desirable and cheaper than urban alternatives (Peiser, 2001). In Asia, most recently China and India are experiencing the largest and most rapid urban sprawl because of their enormous economic transformation which affecting agricultural productivities (Yue, 2011). Generally, majority scholars admit that urban sprawl had indirectly provide negative impacts especially towards the social segregation and environmental degradation (Squires, 2002; Burchell et al., 2002). Strong supported by Hua and Ping (2018), Hua (2018, 2017a), Noor and Rosni (2013) as well as Abdullahs (2012) view that the problems caused by urban sprawl are exceeded the 
expected of benefits due to increasing of population growth that live based on their own desires. Nevertheless, many academicians are invited to provide the ideas on urban sprawl for effectively containment, especially focuses about the sustainability development (Hua and Ping, 2018).

Since urbanization process taking place worldwide and are considered a universal phenomenon, therefore population growth, economy and infrastructure could be responsible to the increasing of this bewildering phenomenon. Specifically, any development of an urban area with no ability to visualize the growth through planning, policies and decision making process could resulted the sprawl. Therefore, urban sprawl is likely to be considered as the development of a city due to unplanned, uncontrolled, and uncoordinated growth, it could impact the wildlife habitat, encroachment of natural resources and farmland, increased environmental degradation, as well as social and economy deprivation (Hua, 2018, 2017b; Tehrany et al., 2013). Malaysia already going towards an over urbanized nation with $75 \%$ of the population is expected to live in urban areas in 2020 (Abdullah, 2012). His study also indicated, urban sprawl in Malaysia will continuously become part of the landscape of metropolitan and other major cities with the expansion of regional economic corridors. Greater Kuala Lumpur, an area surrounded by 10 municipalities surrounding Kuala Lumpur are considered far reaching the socio-economic and cultural conditions. These cities are having desire to compete among each other, and this had caused the economic activities to concentrated in the urban area and leaving the rural areas far behind in term of development. Since Greater Kuala Lumpur had a greater growth in the area and this trend had cause greater number of populations to reside in suburban areas rather than city.

Sepang is considered very significant in term of suburban living and sprawl. The study area was mainly selected based on the rapid urbanization and sudden increase in population especially in 1997-2007. This is probably due to government's decision on the relocation of the administrative of Putrajaya in 1995. Putrajaya is the biggest integrated development with a total land area of 4581.1 ha, conveniently located within the district of Sepang but with separated autonomy. Another integrated development located within Sepang is Cyberjaya, the IT-themed city aspired as Malaysia's Silicon Valley. Cyberjaya is part of Multimedia Super Corridor, a special economic corridor and high technology business district, Federal Government's knowledge based initiative. Sepang also houses KLIA and F1 Sepang circuit, both generated many chain of businesses and employment. This study examined the conceptualization and measurement of sprawl whereby its equates with non-urban e.g. farmland, cropland and open space that change into urban land e.g. building, infrastructures. Therefore, urban sprawl must be considered as the rate of increase relative to physical urban growth or land use change in a space-time context. Consequently the main objective of this study is to assess the land use change from 1990 to 2018 through detection techniques using Land Use Land Cover (LULC) and Normalized Differences Vegetation Index (NDVI). Both methods are considered accurate, common, and effective in change detection for mapping of urban sprawl (Lu et al., 2004).

\section{The review on theoretical for measured urban sprawl}

Another definition by pattern of growth is brought by Ewing and Hamidi (2008), refers urban sprawl as undesirable land use patterns whether scattered, leapfrog, ribbon or continuous low density development and at the same time has poor accessibility and lack of functional open spaces. The growth patterns are usually determined by the 
availability of adjacent land and variations of terrain. Accessibility has direct correlation with the extent of scattered-ness of the pattern. The more scattered the pattern, the lower their accessibility. Ewing also included any urban growth pattern that have poor accessibility and lack of functional open space.

Combination rather than individually separated on the application techniques of remote sensing and GIS in the study for urban sprawl are better especially in monitoring nor simulation for the physical, social and economic data (Mohd Noor et al., 2012). Majority researchers are tends to use remote sensing and GIS to monitor and measure the urban sprawl (Hua, 2018; Noor and Rosni, 2013; Mohd Noor et al., 2012). Nevertheless, having strong definition on sprawl term with focus towards the problematic and undesirable development characteristic which majority stakeholders are debate on. Therefore, the advantageous of using remote sensing is the capability of producing consistent spatial dataset with coverage of larger areas assisted with its high spatial and temporal resolution. In other words, remote sensing can be considered as "unique view" on the spatial temporal change of the urban growth process and land use change (Herold et al., 2003). Another advantageous of using satellite remote sensing are land cover monitoring and detection at various scales to provide useful results (Wilson et al., 2003; Stefanov et al., 2001).

The present technology enable the integration of remote sensing and Geographical Information System (GIS) with Global Positioning System (GPS) allowing land use change detection and assessment become more effective (Muller and Zeller, 2002; Weng, 2002). The technique of mapping urban areas as source of data for modelling and urban growth analysis as well as dynamic change detection in land use land cover was proven as very beneficial (Wilson et al., 2003; Herold et al., 2003; Stefanov et al., 2001).

\section{Materials and methods}

\section{Study area}

The study area is Sepang, Selangor, Malaysia located at $2^{\circ} 45^{\prime} 38^{\prime \prime} \mathrm{N}$ and $101^{\circ} 44^{\prime} 15^{\prime \prime} \mathrm{E}$ with a total coverage of $56150 \mathrm{~km}^{2}$ and the main land use are: built-up areas, vegetation and open spaces (Fig. $1 a$ and $b$. The population within 20 years from 1995 is approximately 90,000 and the number is rising up to 190,000 in 2015 (Statistical Department of Malaysia, 2015). Geographically it is in the southern part of Selangor, neighboring to the district of Hulu Langat in the northeast, district of Kuala Langat in the west, and Petaling in the north and also neighboring to District of Nilai, Negeri Sembilan and surrounding the federal territory and administrative capital of Putrajaya. The municipal administration office originally located in pekan Sepang, a very small town consists of not more than 3 shop houses at that time. When the Kuala Lumpur International Airport (KLIA) was officially inaugurated in 1998, the office was moved to Salak Tinggi. For a second time, after Putrajaya was established and become the new administrative capital of Malaysia, the municipal was moved to Cyberjaya in 2008.

\section{Primary data sources of Landsat thematic mapper (TM) and operational land imager (OLI) and thermal infrared sensor (TIRS)}

Remotely sensed data was acquired from the United State Geological Survey (USGS) Earth Explorer for Landsat data of Thematic Mapper (TM) as well as 
Operational Land Imager (OLI) and Thermal Infrared Sensor (TIRS). Supported by Landsat data, the boundary of Sepang district, Malaysia is based on the Department of Survey and Mapping Malaysia (JUPEM), which is important for abstracting process on the raw map using Area of Interest (AOI) technique in mapping procedures. The details on primary satellite data can be shown in Table 1.

Table 1. Primary satellite data of Landsat TM and OLI/TIRS

\begin{tabular}{c|c|c|c|c|c|c}
\hline Sensors & Month/day & Year & Spatial resolution (m) & Time & Path/row & $\begin{array}{c}\text { Band } \\
\text { combination }\end{array}$ \\
\hline \multirow{5}{*}{ Landsat TM } & $12 / 27$ & 1990 & 30 & $10.30 \mathrm{am}$ & $127 / 58$ & \\
& $11 / 25$ & 1992 & 30 & $11.15 \mathrm{am}$ & $127 / 58$ & \\
& $11 / 28$ & 1994 & 30 & $10.27 \mathrm{am}$ & $127 / 58$ & \\
& $06 / 26$ & 1996 & 30 & $10.47 \mathrm{am}$ & $127 / 58$ & \\
& $02 / 08$ & 1998 & 30 & $10.39 \mathrm{am}$ & $127 / 58$ & \\
& $03 / 17$ & 2000 & 30 & $11.06 \mathrm{am}$ & $127 / 58$ & $1,2,3,4,7$ \\
& $05 / 02$ & 2002 & 30 & $10.18 \mathrm{am}$ & $127 / 58$ & \\
& $12 / 23$ & 2004 & 30 & $10.48 \mathrm{am}$ & $127 / 58$ & \\
& $03 / 02$ & 2006 & 30 & $11.49 \mathrm{am}$ & $127 / 58$ & \\
& $07 / 29$ & 2008 & 30 & $10.42 \mathrm{am}$ & $127 / 58$ & \\
& $01 / 02$ & 2010 & 30 & $10.25 \mathrm{am}$ & $127 / 58$ & \\
& $06 / 04$ & 2012 & 30 & $10.29 \mathrm{am}$ & $127 / 58$ & \\
& $03 / 24$ & 2014 & 30 & $10.18 \mathrm{am}$ & $127 / 58$ & \\
& $03 / 29$ & 2016 & 30 & $11.13 \mathrm{am}$ & $127 / 58$ & $2,3,4,5,7$ \\
& $04 / 04$ & 2018 & 30 & $10.30 \mathrm{am}$ & $127 / 58$ & \\
\hline
\end{tabular}

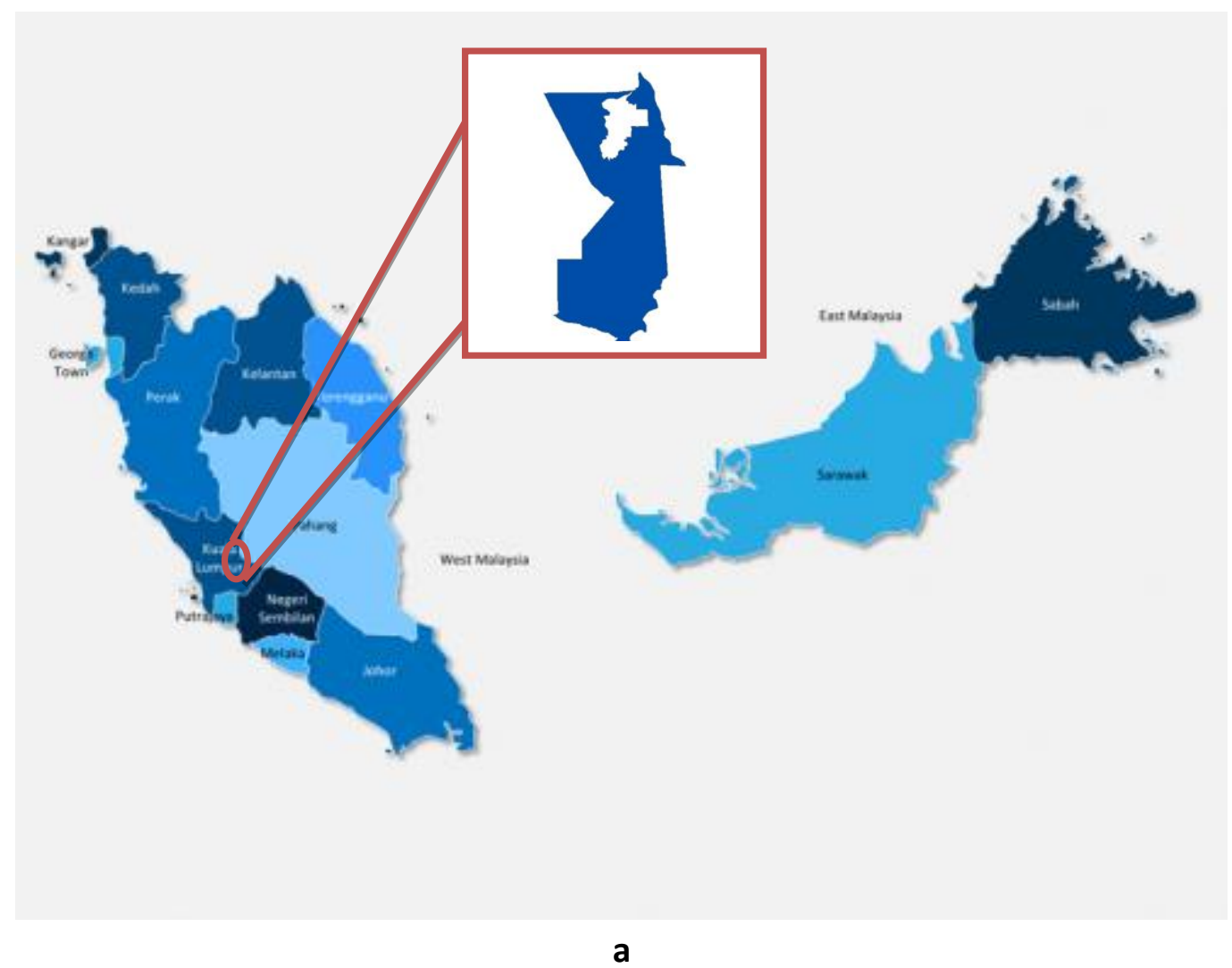




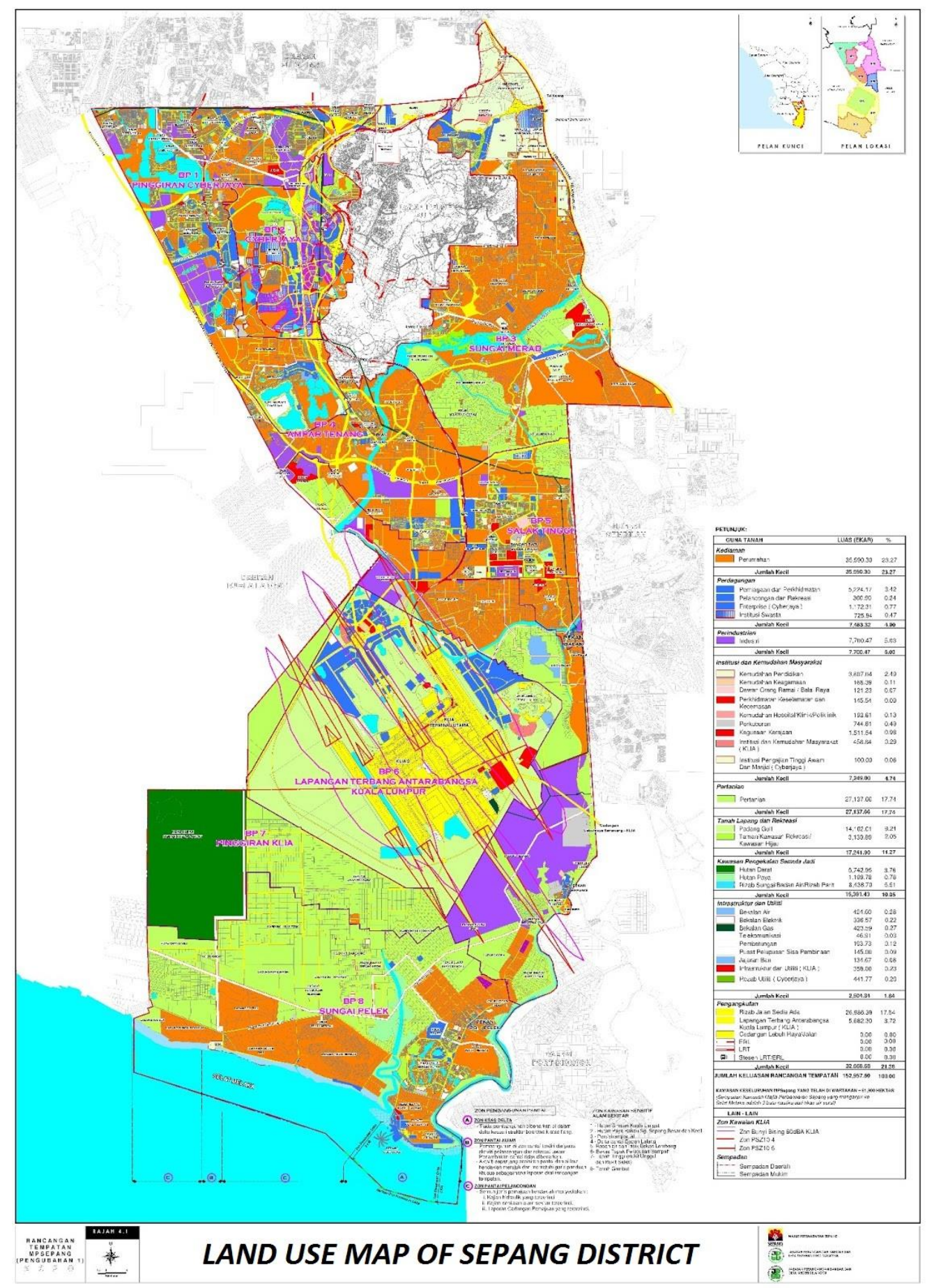

b

Figure 1. a Sepang district as study area in the research study. $\boldsymbol{b}$ The spatial distribution of Sepang District (Source: Sepang Municipal Council 2016)

\section{Data preprocessing and land use/land cover classification}

It is essential for a newly obtained time series of remotely sensed data to be preprocessed before any analytical process are made. First, using ArcGIS Ver. 10.1, the images have to go through pre-processing for geo-referencing, mosaicking, and sub 
setting where only then, the specific area can be selected through Area of Interest (AOI) technique (Behera et al., 2012).

The main purposes to conduct preprocessing are to correct the sensor- and platformspecific radiometric and geometric distortions of data. This correction technique on the radiometric is required because of the variation in scene illumination and viewing geometry, atmospheric conditions, and sensor noise and responses. Fortunately, all satellite images obtained is cloud free or $<10 \%$ cloud coverage (Tan et al., 2010). To avoid error and imprecise interpretation, the images for Landsat TM and OLI/TIRS were in original resolution of $30 \mathrm{~m}$ (Table 1).

Next, further processing for band combination of 3-2-1 in Landsat TM and 4-3-2 in Landsat OLI/TIRS are carried out in ArcGIS 10. Then classification of land use is conducted in ENVI Version 4.0. Classification was performed using Maximum Likelihood supervised using selected regions and Regions of Interest (ROI), which based on delineated classes of built-up area, vegetation area, water bodies, and open space area (Table 2). The built-up areas classes consists of residential, industrial, commercial, administration, cemetery and transportation, and sewage treatment plant. The vegetation classes consists of all forest and agricultural land, as well as open space whereby it include barren land. The final class is the water bodies which consists of rivers, lakes, stream, canals and reservoirs.

Table 2. Land use classification based on maximum likelihood supervised techniques

\begin{tabular}{c|c}
\hline Land use class & Definition \\
\hline Built up area & $\begin{array}{r}\text { Includes all residential, industrial, commercial, administration, cemetery and } \\
\text { transportation, and sewage treatment plant }\end{array}$ \\
\hline Vegetation area & Includes all forest field and agricultural lands \\
\hline Water bodies & Includes all water bodies (river, lakes, gravels, stream, canals, and reservoirs) \\
\hline Open space area & Includes all land area that are in soil and barren area due to the human activities \\
\hline
\end{tabular}

\section{Accuracy assessment}

It is compulsory to conduct accuracy assessment of classified images from 1990 to 2018 (i.e. 15 images) to ensure accuracy, integrity and quality. Kappa tests are used to measure the accuracy of classification which have capability to test all confusion matrix of elements based on minimum requirement (Halmy et al., 2015). The Kappa tests can be measured based on the producer and user rating of assignment, which can be interpreted in formula as Equation 1:

$$
K=\frac{P(A)-P(E)}{1-P(E)}
$$

where, $P(A)$ is the total of $k$ raters agree, and $P(E)$ is the total of $k$ raters which expected to agree by chance (El-Kawy et al., 2011; Pontius and Millones, 2011). The accuracy of user can be explained as probability defined the pixel on image to represent a class on ground, while accuracy of producer is the probability pixel is correctly classified and usually it determine how good for particular area can be classified (Pontius and Millones, 2011). Therefore, four (4) classes had been set up earlier, whereby the delineated should be 50 points and above for each category to enhance the accuracy 
assessment percentage (El-Kawy et al., 2011; Pontius and Malanson, 2005). So, the accuracy assessment for 1990, 1992, 1994, 1996, 1998, 2000, 2002, 2004, 2006, 2008, $2010,2012,2014,2016$, and 2018 are having the kappa value of $0.87,0.84,0.82,0.83$, $0.86,0.88,0.91,0.80,0.82,0.82,0.90,0.86,0.85,0.84$, and 0.91 , respectively (Table $3 a-o$ ). Identified categories of LULC in accuracy assessment are considered achieved the required minimum, which is need to be at least $80 \%$ (Weng, 2010). Hence, the data can be exported into ENVI 4.0 for further analysis.

Table 3. a The accuracy assessment for 1990 of Sepang district

\begin{tabular}{c|c|c|c|c|c}
\hline Class name (1990) & $\begin{array}{c}\text { Reference } \\
\text { total }\end{array}$ & $\begin{array}{c}\text { Classified } \\
\text { total }\end{array}$ & $\begin{array}{c}\text { Number } \\
\text { correct }\end{array}$ & $\begin{array}{c}\text { Producers } \\
\text { accuracy }(\%)\end{array}$ & $\begin{array}{c}\text { User } \\
\text { accuracy }(\%)\end{array}$ \\
\hline Built up area & 18 & 14 & 11 & 61.11 & 78.57 \\
Vegetation area & 558 & 560 & 557 & 99.82 & 99.46 \\
Water bodies & 0 & 4 & 0 & 0.00 & 0.00 \\
Open space area & 22 & 20 & 20 & 90.91 & 100.00 \\
\hline
\end{tabular}

Overall classification accuracy $=98.33 \%$; Kappa coefficient $=0.8654$

Table 3. $\boldsymbol{b}$ The accuracy assessment for 1992 of Sepang district

\begin{tabular}{c|c|c|c|c|c}
\hline Class name (1992) & $\begin{array}{c}\text { Reference } \\
\text { total }\end{array}$ & $\begin{array}{c}\text { Classified } \\
\text { total }\end{array}$ & $\begin{array}{c}\text { Number } \\
\text { correct }\end{array}$ & $\begin{array}{c}\text { Producers } \\
\text { accuracy }(\%)\end{array}$ & $\begin{array}{c}\text { User } \\
\text { accuracy }(\%)\end{array}$ \\
\hline Built up area & 245 & 148 & 120 & 48.98 & 81.08 \\
Vegetation area & 4182 & 4181 & 4179 & 99.93 & 99.95 \\
Water bodies & 50 & 63 & 38 & 76.00 & 60.32 \\
Open space area & 83 & 168 & 70 & 84.34 & 41.67 \\
\hline
\end{tabular}

Overall classification accuracy $=96.64 \%$; Kappa coefficient $=0.8357$

Table 3. $\mathrm{c}$ The accuracy assessment for 1994 of Sepang district

\begin{tabular}{c|c|c|c|c|c}
\hline Class name (1994) & $\begin{array}{c}\text { Reference } \\
\text { total }\end{array}$ & $\begin{array}{c}\text { Classified } \\
\text { total }\end{array}$ & $\begin{array}{c}\text { Number } \\
\text { correct }\end{array}$ & $\begin{array}{c}\text { Producers } \\
\text { accuracy }(\boldsymbol{\%})\end{array}$ & $\begin{array}{c}\text { User accuracy } \\
(\boldsymbol{\%})\end{array}$ \\
\hline Built up area & 277 & 183 & 126 & 45.49 & 68.85 \\
Vegetation area & 3717 & 3703 & 3667 & 98.65 & 99.03 \\
Water bodies & 90 & 89 & 89 & 98.89 & 100.00 \\
Open space area & 163 & 272 & 156 & 95.71 & 57.35 \\
\hline
\end{tabular}

Overall classification accuracy $=95.08 \% ;$ Kappa coefficient $=0.8217$

Table 3. $\boldsymbol{d}$ The accuracy assessment for 1996 of Sepang district

\begin{tabular}{c|c|c|c|c|c}
\hline Class name (1996) & $\begin{array}{c}\text { Reference } \\
\text { total }\end{array}$ & $\begin{array}{c}\text { Classified } \\
\text { total }\end{array}$ & $\begin{array}{c}\text { Number } \\
\text { correct }\end{array}$ & $\begin{array}{c}\text { Producers } \\
\text { accuracy }(\%)\end{array}$ & $\begin{array}{c}\text { User } \\
\text { accuracy (\%) }\end{array}$ \\
\hline Built up area & 778 & 927 & 497 & 63.88 & 53.61 \\
Vegetation area & 10102 & 9387 & 9383 & 92.88 & 99.96 \\
Water bodies & 162 & 603 & 158 & 97.53 & 26.20 \\
Open space area & 721 & 846 & 703 & 97.50 & 83.10 \\
\hline
\end{tabular}

Overall classification accuracy $=94.31 \%$; Kappa coefficient $=0.8279$ 
Table 3. $\boldsymbol{e}$ The accuracy assessment for 1998 of Sepang district

\begin{tabular}{c|c|c|c|c|c}
\hline Class name (1998) & $\begin{array}{c}\text { Reference } \\
\text { total }\end{array}$ & $\begin{array}{c}\text { Classified } \\
\text { total }\end{array}$ & $\begin{array}{c}\text { Number } \\
\text { correct }\end{array}$ & $\begin{array}{c}\text { Producers } \\
\text { accuracy }(\%)\end{array}$ & $\begin{array}{c}\text { User } \\
\text { accuracy }(\%)\end{array}$ \\
\hline Built up area & 3265 & 2702 & 2330 & 71.36 & 66.12 \\
Vegetation area & 8638 & 8329 & 8328 & 96.41 & 99.99 \\
Water bodies & 211 & 290 & 141 & 95.52 & 48.62 \\
Open space area & 199 & 992 & 152 & 94.38 & 80.82 \\
\hline
\end{tabular}

Overall classification accuracy $=97.94 \% ;$ Kappa coefficient $=0.8624$

Table 3. $f$ The accuracy assessment for 2000 of Sepang district

\begin{tabular}{c|c|c|c|c|c}
\hline Class name (2000) & $\begin{array}{c}\text { Reference } \\
\text { total }\end{array}$ & $\begin{array}{c}\text { Classified } \\
\text { total }\end{array}$ & $\begin{array}{c}\text { Number } \\
\text { correct }\end{array}$ & $\begin{array}{c}\text { Producers } \\
\text { accuracy }(\boldsymbol{\%})\end{array}$ & $\begin{array}{c}\text { User accuracy } \\
(\boldsymbol{\%})\end{array}$ \\
\hline Built up area & 1581 & 1203 & 1059 & 91.98 & 88.03 \\
Vegetation area & 7541 & 7488 & 7484 & 99.24 & 99.95 \\
Water bodies & 104 & 437 & 100 & 96.15 & 88.22 \\
Open space area & 136 & 234 & 51 & 37.50 & 21.79 \\
\hline
\end{tabular}

Overall classification accuracy $=95.86 \% ;$ Kappa coefficient $=0.8758$

Table 3. $\mathrm{g}$ The accuracy assessment for 2002 of Sepang district

\begin{tabular}{c|c|c|c|c|c}
\hline Class name (2002) & $\begin{array}{c}\text { Reference } \\
\text { total }\end{array}$ & $\begin{array}{c}\text { Classified } \\
\text { total }\end{array}$ & $\begin{array}{c}\text { Number } \\
\text { correct }\end{array}$ & $\begin{array}{c}\text { Producers } \\
\text { accuracy (\%) })\end{array}$ & $\begin{array}{c}\text { User } \\
\text { accuracy (\%) }\end{array}$ \\
\hline Built up area & 1654 & 1646 & 1594 & 96.37 & 96.84 \\
Vegetation area & 5776 & 5675 & 5630 & 97.47 & 99.21 \\
Water bodies & 215 & 275 & 137 & 63.72 & 49.82 \\
Open space area & 115 & 164 & 107 & 93.04 & 65.24 \\
\hline
\end{tabular}

Overall classification accuracy $=96.24 \%$; Kappa coefficient $=0.9080$

Table 3. $\boldsymbol{h}$ The accuracy assessment for 2004 of Sepang district

\begin{tabular}{c|c|c|c|c|c}
\hline Class name (2004) & $\begin{array}{c}\text { Reference } \\
\text { total }\end{array}$ & $\begin{array}{c}\text { Classified } \\
\text { total }\end{array}$ & $\begin{array}{c}\text { Number } \\
\text { correct }\end{array}$ & $\begin{array}{c}\text { Producers } \\
\text { accuracy (\%) }\end{array}$ & $\begin{array}{c}\text { User } \\
\text { accuracy (\%) }\end{array}$ \\
\hline Built up area & 1982 & 1701 & 1581 & 79.77 & 92.95 \\
Vegetation area & 6654 & 6642 & 6533 & 98.18 & 98.36 \\
Water bodies & 207 & 54 & 11 & 5.31 & 20.37 \\
Open space area & 79 & 525 & 63 & 79.75 & 12.00 \\
\hline
\end{tabular}

Overall classification accuracy $=92.77 \%$; Kappa coefficient $=0.8025$

Table 3. $i$ The accuracy assessment for 2006 of Sepang district

\begin{tabular}{c|c|c|c|c|c}
\hline Class name (2006) & $\begin{array}{c}\text { Reference } \\
\text { total }\end{array}$ & $\begin{array}{c}\text { Classified } \\
\text { total }\end{array}$ & $\begin{array}{c}\text { Number } \\
\text { correct }\end{array}$ & $\begin{array}{c}\text { Producers } \\
\text { accuracy (\%) }\end{array}$ & $\begin{array}{c}\text { User } \\
\text { accuracy (\%) }\end{array}$ \\
\hline Built up area & 1489 & 1072 & 1072 & 71.99 & 80.60 \\
Vegetation area & 4914 & 4725 & 4725 & 96.15 & 100.00 \\
Water bodies & 116 & 477 & 97 & 83.62 & 20.34 \\
Open space area & 303 & 290 & 187 & 61.72 & 64.48 \\
\hline
\end{tabular}

Overall classification accuracy $=93.14 \%$; Kappa coefficient $=0.8156$ 
Table 3. $j$ The accuracy assessment for 2008 of Sepang district

\begin{tabular}{c|c|c|c|c|c}
\hline Class name (2008) & $\begin{array}{c}\text { Reference } \\
\text { total }\end{array}$ & $\begin{array}{c}\text { Classified } \\
\text { total }\end{array}$ & $\begin{array}{c}\text { Number } \\
\text { correct }\end{array}$ & $\begin{array}{c}\text { Producers } \\
\text { accuracy (\%) })\end{array}$ & $\begin{array}{c}\text { User } \\
\text { accuracy (\%) }\end{array}$ \\
\hline Built up area & 2149 & 1813 & 1517 & 70.59 & 83.67 \\
Vegetation area & 6312 & 6045 & 5975 & 94.66 & 90.84 \\
Water bodies & 241 & 245 & 111 & 46.06 & 45.31 \\
Open space area & 113 & 712 & 105 & 92.92 & 88.81 \\
\hline
\end{tabular}

Overall classification accuracy $=90.44 \%$; Kappa coefficient $=0.8225$

Table 3. $\boldsymbol{k}$ The accuracy assessment for 2010 of Sepang district

\begin{tabular}{c|c|c|c|c|c}
\hline Class name (2010) & $\begin{array}{c}\text { Reference } \\
\text { total }\end{array}$ & $\begin{array}{c}\text { Classified } \\
\text { total }\end{array}$ & $\begin{array}{c}\text { Number } \\
\text { correct }\end{array}$ & $\begin{array}{c}\text { Producers } \\
\text { accuracy (\%) }\end{array}$ & $\begin{array}{c}\text { User accuracy } \\
(\boldsymbol{\%})\end{array}$ \\
\hline Built up area & 3073 & 2926 & 2835 & 92.26 & 96.89 \\
Vegetation area & 5169 & 5096 & 5044 & 97.58 & 98.98 \\
Water bodies & 145 & 124 & 97 & 66.90 & 78.23 \\
Open space area & 65 & 306 & 64 & 98.46 & 80.92 \\
\hline
\end{tabular}

Overall classification accuracy $=95.13 \%$; Kappa coefficient $=0.9034$

Table 3. 1 The accuracy assessment for 2012 of Sepang district

\begin{tabular}{c|c|c|c|c|c}
\hline Class name (2012) & $\begin{array}{c}\text { Reference } \\
\text { total }\end{array}$ & $\begin{array}{c}\text { Classified } \\
\text { total }\end{array}$ & $\begin{array}{c}\text { Number } \\
\text { correct }\end{array}$ & $\begin{array}{c}\text { Producers } \\
\text { accuracy (\%) }\end{array}$ & $\begin{array}{c}\text { User accuracy } \\
(\boldsymbol{\%})\end{array}$ \\
\hline Built up area & 2743 & 2473 & 2379 & 86.73 & 96.20 \\
Vegetation area & 5228 & 5134 & 5075 & 97.07 & 98.85 \\
Water bodies & 145 & 243 & 135 & 93.10 & 55.65 \\
Open space area & 135 & 401 & 97 & 71.85 & 24.19 \\
\hline
\end{tabular}

Overall classification accuracy $=93.15 \%$; Kappa coefficient $=0.8643$

Table 3. $\boldsymbol{m}$ The accuracy assessment for 2014 of Sepang district

\begin{tabular}{c|c|c|c|c|c}
\hline Class name (2014) & $\begin{array}{c}\text { Reference } \\
\text { total }\end{array}$ & $\begin{array}{c}\text { Classified } \\
\text { total }\end{array}$ & $\begin{array}{c}\text { Number } \\
\text { correct }\end{array}$ & $\begin{array}{c}\text { Producers } \\
\text { accuracy (\%) }\end{array}$ & $\begin{array}{c}\text { User accuracy } \\
(\%)\end{array}$ \\
\hline Built up area & 3829 & 3172 & 2943 & 76.86 & 92.78 \\
Vegetation area & 3156 & 2995 & 2934 & 92.97 & 97.96 \\
Water bodies & 155 & 289 & 152 & 98.06 & 52.60 \\
Open space area & 318 & 1002 & 311 & 97.80 & 31.04 \\
\hline
\end{tabular}

Overall classification accuracy $=95.01 \%$; Kappa coefficient $=0.8523$

Table 3. $\boldsymbol{n}$ The accuracy assessment for 2016 of Sepang district

\begin{tabular}{c|c|c|c|c|c}
\hline Class name (2016) & $\begin{array}{c}\text { Reference } \\
\text { total }\end{array}$ & $\begin{array}{c}\text { Classified } \\
\text { total }\end{array}$ & $\begin{array}{c}\text { Number } \\
\text { correct }\end{array}$ & $\begin{array}{c}\text { Producers } \\
\text { accuracy (\%) }\end{array}$ & $\begin{array}{c}\text { User accuracy } \\
(\%)\end{array}$ \\
\hline Built up area & 4095 & 3635 & 3464 & 84.59 & 95.30 \\
Vegetation area & 5672 & 5445 & 5442 & 95.94 & 99.94 \\
Water bodies & 229 & 355 & 226 & 98.69 & 87.66 \\
Open space area & 150 & 711 & 107 & 71.33 & 50.05 \\
\hline
\end{tabular}

Overall classification accuracy $=91.06 \%$; Kappa coefficient $=0.8385$ 
Table 3. $o$ The accuracy assessment for 2018 of Sepang district

\begin{tabular}{c|c|c|c|c|c}
\hline Class name (2018) & $\begin{array}{c}\text { Reference } \\
\text { total }\end{array}$ & $\begin{array}{c}\text { Classified } \\
\text { total }\end{array}$ & $\begin{array}{c}\text { Number } \\
\text { correct }\end{array}$ & $\begin{array}{c}\text { Producers } \\
\text { accuracy (\%) }\end{array}$ & $\begin{array}{c}\text { User accuracy } \\
(\%)\end{array}$ \\
\hline Built up area & 2158 & 2155 & 1992 & 92.31 & 92.44 \\
Vegetation area & 4978 & 4885 & 4851 & 97.45 & 99.30 \\
Water bodies & 108 & 120 & 108 & 100.00 & 90.00 \\
Open space area & 337 & 421 & 299 & 88.72 & 71.02 \\
\hline
\end{tabular}

Overall classification accuracy $=95.63 \% ;$ Kappa coefficient $=0.9115$

\section{Analysis of change detection in land use land cover}

In LULC change detection, post-classification detection technique is proposed in this study using ENVI 4.0, where two classified images were compared to provide the information of changes on the pixel basis. In other words, these two images were interpreted to produce the changes "from- to" information. A $30 \times 30 \mathrm{~m}$ to ground resolution of Landsat TM and Landsat OLI/TIRS were resampled and geo-rectified based on WGS84 UTM with RMSE less than 0.5 pixels were projected. Then, classified images based on two comparisons of data sets using cross-tabulation to determine the qualitative and quantitative changes for the periods from 1990 to 2018. The frequency and percentage of changes can be calculated according to simple formula as Equations 2 and 3:

$$
\begin{gathered}
K=F-I \\
A=\frac{(F-I)}{I} \times 100
\end{gathered}
$$

where, $\mathrm{K}$ is the magnitude of changes, $\mathrm{A}$ is the percentage of changes, $\mathrm{F}$ is the first data, and $I$ is the references data (Mahmud and Achide, 2012). This research study uses LULC methods to map the urban sprawl by determine the differences of land use changes and to explain the percentages changes within the period of time.

\section{Normalized difference vegetation index (NDVI)}

Normalized difference vegetation index (NDVI) is measuring the vegetation through quantifies between near-infrared of differences (which refer to the stronger reflected light by vegetation) and red light (which refer to the light that absorbs by vegetation). The NDVI value is ranges from -1 to 1 , but it is no exact boundary line between each type of land cover. For instance, when the value is negatives, which showing the pixel are in water coverage; meanwhile the value that close to +1 , then the result are having high possibility of green leaves surrounding the area. Nevertheless, when the value of NDVI is close to zero, then the land use indicates no green leaves and probably showing an urbanized area. The NDVI can be interpreted into formula as Equation 4:

$$
N D V I=\frac{(N I R-R E D)}{(N I R+R E D)}
$$

where, NIR - RED and NIR + RED indicate the surface reflectance averaged over ranges of wavelengths in the visible of red $(\lambda \sim 0.6 \mu \mathrm{m})$ and near infrared, IR $(\lambda \sim 0.8 \mu \mathrm{m})$, 
respectively. In other words, NDVI is a standardized way to measure the healthy vegetation. When the NDVI value is higher, then the healthier is the vegetation at the study area.

\section{Normalized difference built-up index (NDBI)}

Having similar with NDVI, the normalized difference built-up index (NDBI) is used to measured the build-up area through quantifies between differences of short-wave infrared (SWIR) and near-infrared (NIR). The NDBI value is ranges from -1 to 1 , whereby the negative value showing the pixel are non-built-up coverage area; meanwhile the positive value are having high possibility of built-up area surrounding the environment. The NDBI can be expressed into formula as Equation 5:

$$
N D B I=\frac{(S W I R-N I R)}{(S W I R+N I R)}
$$

where, SWIR - NIR and SWIR + NIR can be defined as surface reflectance averaged over ranges of wavelengths in the short infrared $(\lambda \sim 0.7 \mu \mathrm{m})$ and near infrared $(\lambda \sim 0.8 \mu \mathrm{m})$. When the NDBI value is higher, this circumstances indicate the study area is clustered with highly built-up activities within surrounding area.

\section{Results and discussion}

According to Table 4, the result indicated the density of LULC changes from 1990 to 2018 with four classes: built-up area, vegetation area, water bodies, and open space area (Fig. 2). Except in year 1992, the built-up area (BUA) class is observed to have continuously increase for 25 years. The percentage of increment is about $25.4 \%$ from 1990 to 2018. The study concluded that BUA classes are considered having the most increment due to rapid urbanization and population growth. It is followed by OSA class from 1990 to 2004 with an increment of $4.75 \%$ in average but beginning to decrease by $18.5 \%$ in the next 13 years. In other words, majority OSA class has gain benefit from the vegetation area (VA), and the most open space is suspected to change into BUA and/or other classes. Vegetation Area (VA) class consistently decreasing from 1990 to 2018 (Fig. 3) by 64.33\%. This amount to 36123.07 ha of land. Except for waterbodies which has not seen any significant change, this uppermost land use changes is due to high demand in BOA to cater with population need and demand for residentialindustrial-commercial activities as well as transportation facilities.

Table 4. Change of the LULC density classes from 1990 to 2018

\begin{tabular}{|c|c|c|c|c|c|c|c|c|c|c|c|c|c|c|c|c|}
\hline \multirow{2}{*}{$\begin{array}{c}\text { LULC } \\
\text { density } \\
\text { classes }\end{array}$} & \multicolumn{2}{|c|}{1990} & \multicolumn{2}{|c|}{1992} & \multicolumn{2}{|c|}{1994} & \multicolumn{2}{|c|}{1996} & \multicolumn{2}{|c|}{1998} & \multicolumn{2}{|c|}{2000} & \multicolumn{2}{|c|}{2002} & \multicolumn{2}{|c|}{2004} \\
\hline & Ha & $\%$ & Ha & $\%$ & На & $\%$ & Ha & $\%$ & Ha & $\%$ & Ha & $\%$ & Ha & $\%$ & На & $\%$ \\
\hline BUA & 8423 & 15 & 5054 & 9 & 7299 & 13 & 8984 & 16 & 12915 & 23 & 15722 & 28 & 11792 & 21 & 10107 & 18 \\
\hline VA & 43235 & 77 & 45481 & 81 & 40428 & 72 & 43236 & 77 & 38743 & 69 & 34251 & 61 & 38743 & 69 & 38182 & 68 \\
\hline WB & 3931 & 7 & 1685 & 3 & 7299 & 13 & 2246 & 4 & 2808 & 5 & 4492 & 8 & 2246 & 4 & 562 & 1 \\
\hline OSA & 561 & 1 & 3930 & 7 & 1124 & 2 & 1684 & 3 & 1684 & 3 & 1685 & 3 & 3369 & 6 & 7299 & 13 \\
\hline
\end{tabular}




\begin{tabular}{|c|c|c|c|c|c|c|c|c|c|c|c|c|c|c|}
\hline & \multicolumn{2}{|c|}{2006} & \multicolumn{2}{|c|}{2008} & \multicolumn{2}{|c|}{2010} & \multicolumn{2}{|c|}{2012} & \multicolumn{2}{|c|}{2014} & \multicolumn{2}{|c|}{2016} & \multicolumn{2}{|c|}{2018} \\
\hline & Ha & $\%$ & На & $\%$ & Ha & $\%$ & На & $\%$ & Ha & $\%$ & На & $\%$ & Ha & $\%$ \\
\hline BUA & 11230 & 20 & 17968 & 32 & 17968 & 32 & 21337 & 38 & 21899 & 39 & 21337 & 38 & 21898 & 39 \\
\hline VA & 34813 & 62 & 33690 & 60 & 32006 & 57 & 28637 & 51 & 30321 & 54 & 30321 & 54 & 29759 & 53 \\
\hline WB & 3931 & 7 & 2246 & 4 & 2807 & 5 & 5053 & 9 & 1123 & 2 & 2246 & 4 & 1685 & 3 \\
\hline OSA & 6176 & 11 & 2246 & 4 & 3369 & 6 & 1123 & 2 & 2807 & 5 & 2246 & 4 & 2808 & 5 \\
\hline
\end{tabular}
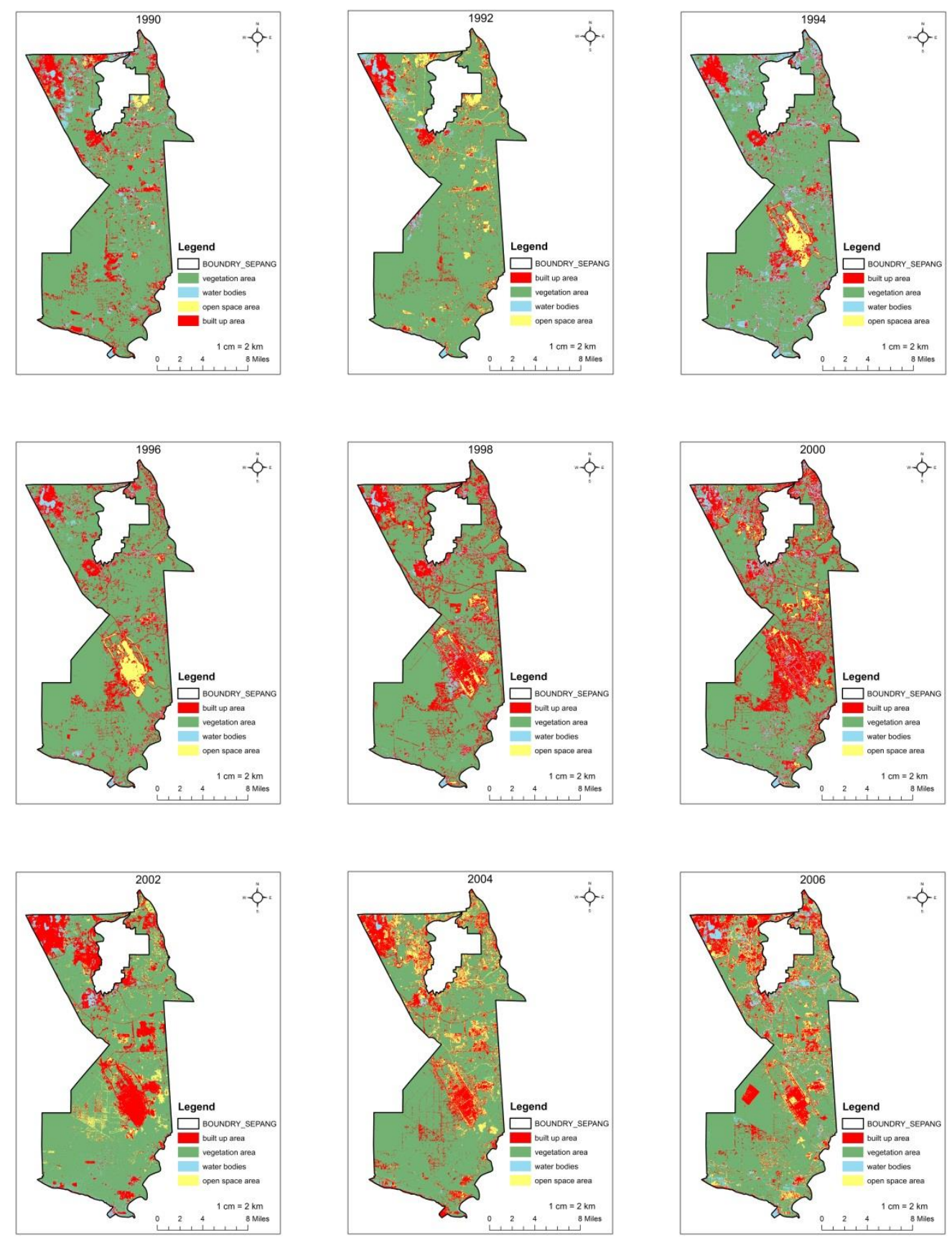

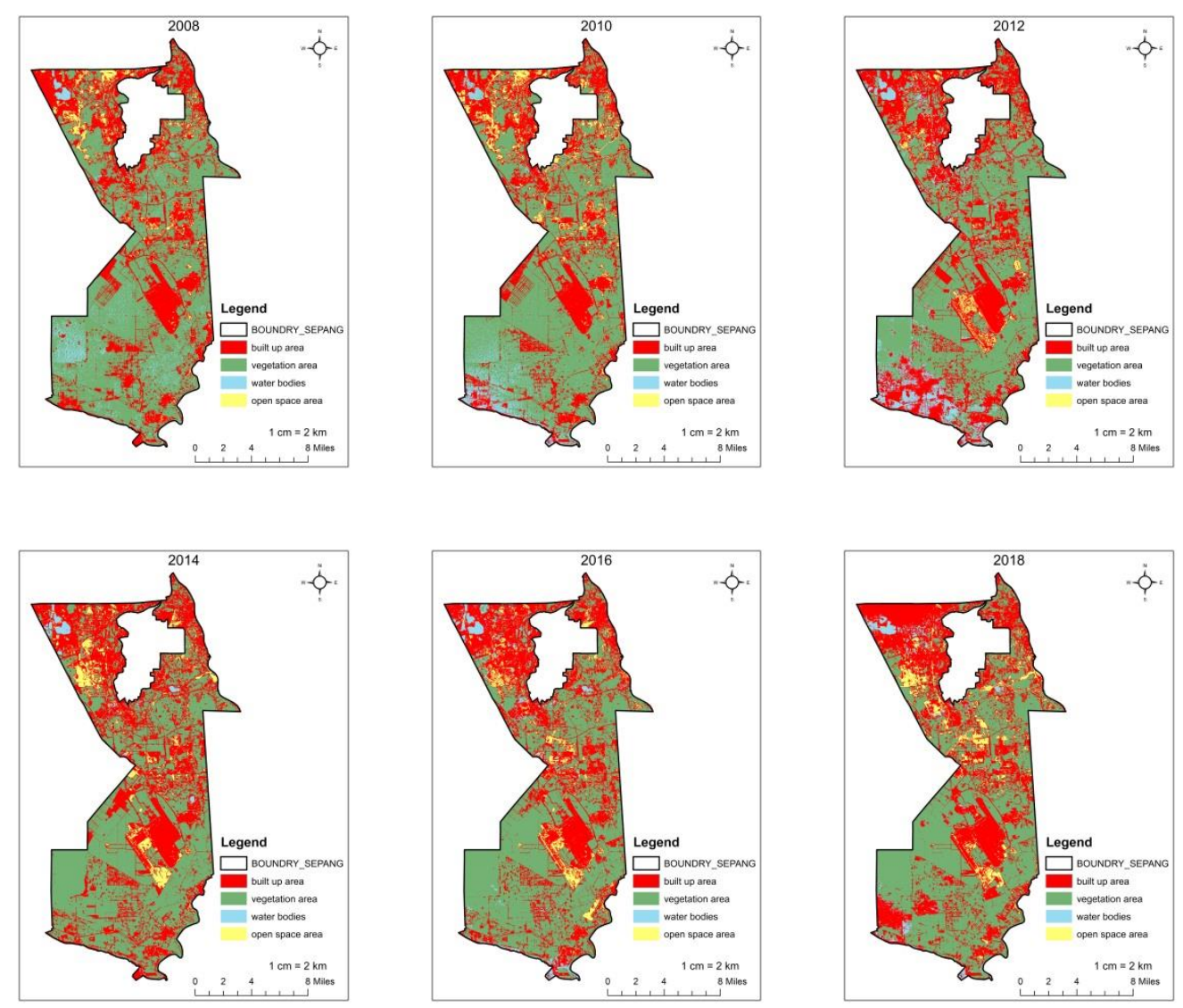

Figure 2. The LULC change from 1990 to 2018 in Sepang district

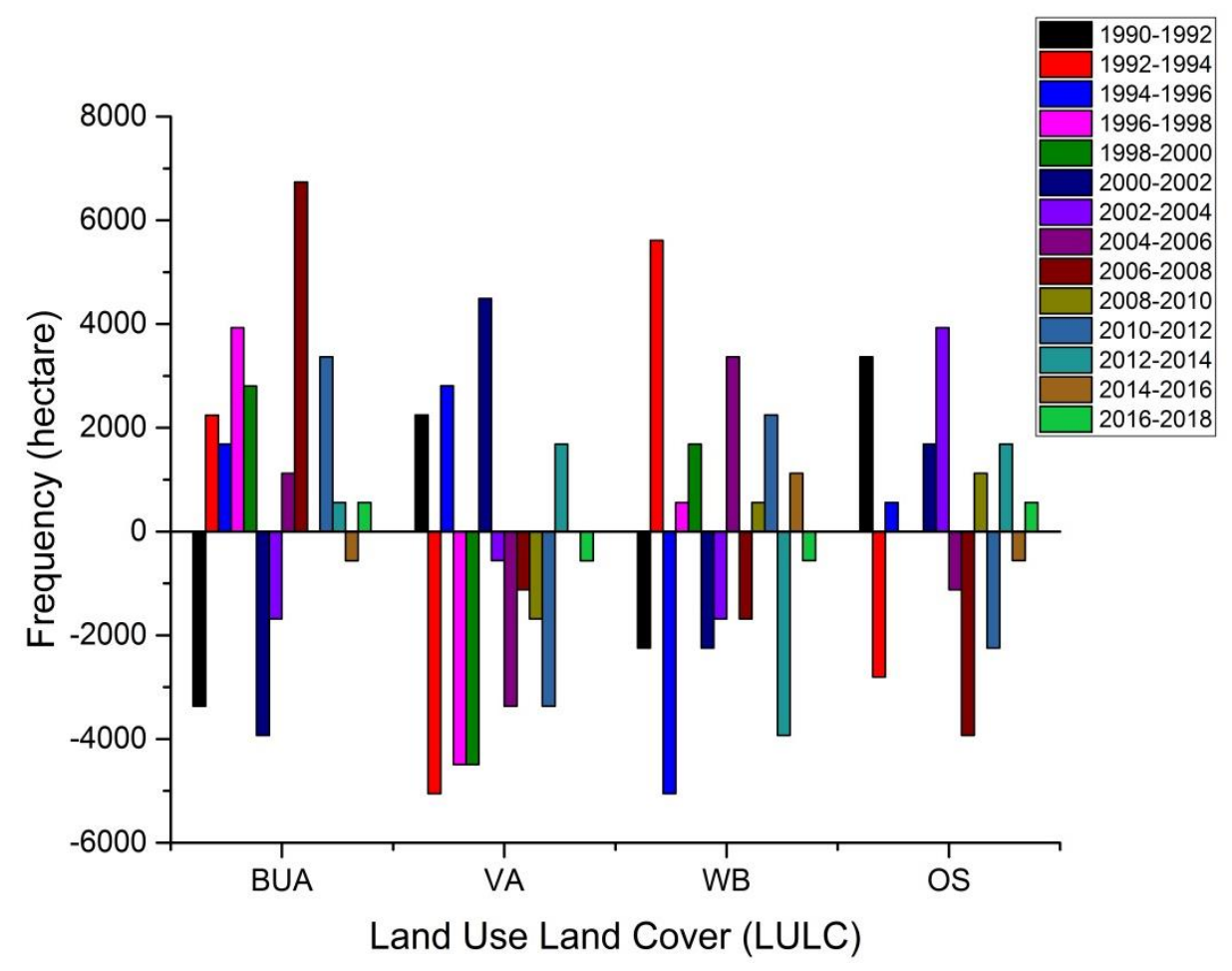

APPLIED ECOLOGY AND ENVIRONMENTAL RESEARCH 17(3):5583-5602.

http://www.aloki.hu • ISSN 15891623 (Print) • ISSN 17850037 (Online)

DOI: http://dx.doi.org/10.15666/aeer/1703_55835602

(C) 2019, ALÖKI Kft., Budapest, Hungary 


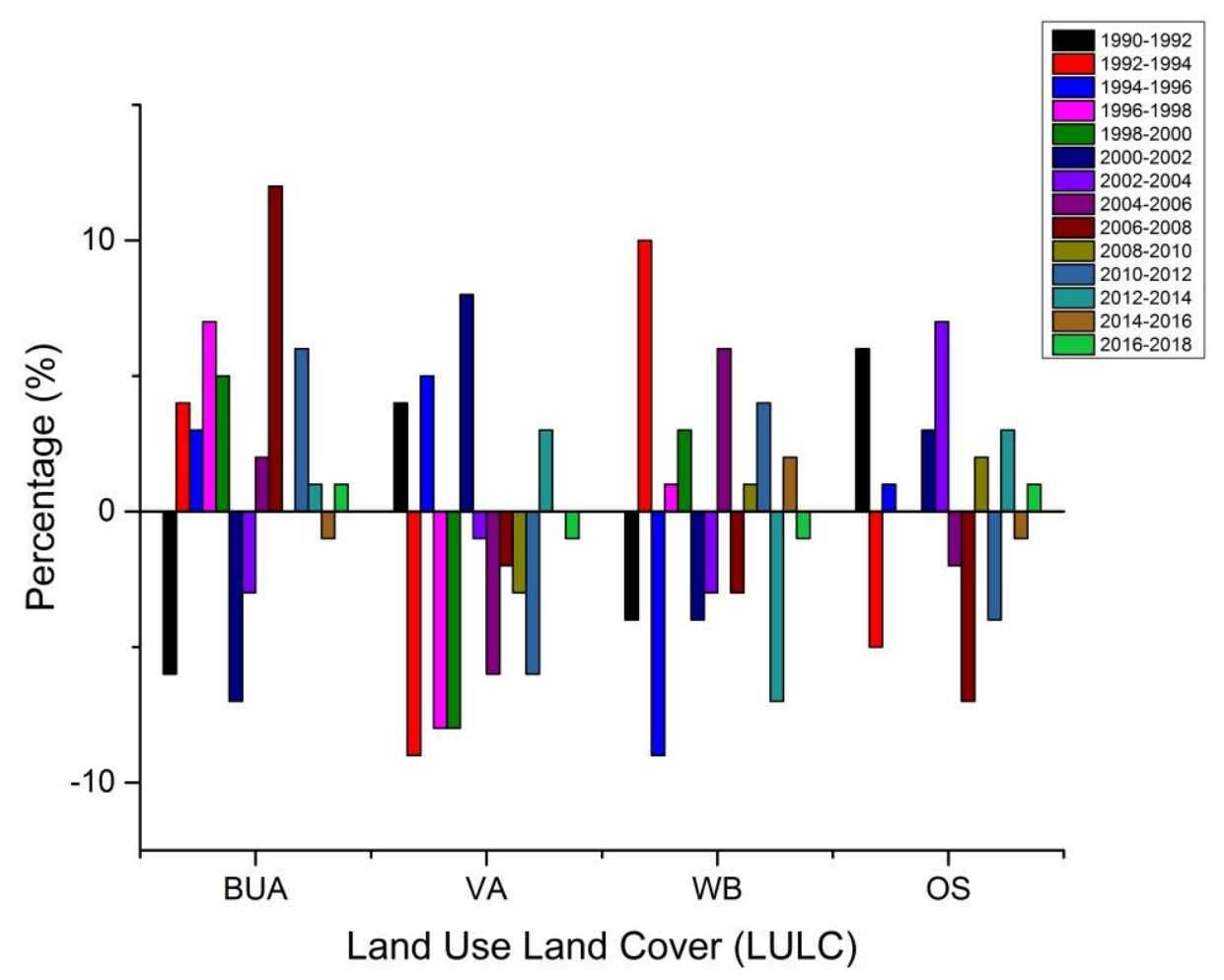

Figure 3. The comparison of areas and rate of changes in LULC classes between each two years from 1990 to 2018

Combining LULC change with Normalized Difference Vegetation Index (NDVI) and Normalized Difference Built-up Index (NDBI) techniques is considered recent and novelty. An NDVI is an equation that takes into account the amount of infrared reflected by plants. In classification process, supervised classification method based maximum likelihood algorithm was employed for NDVI, which is based on a set of user-defined classes and training areas through creating appropriate spectral signatures from Landsat TM and OLI/ TIRS. The result of changes of NDVI density classes for 25 years indicated that the vegetation index gradually reduced about $27.91 \%$ from year 1990 to year 2010, but the value sustained about $28.75 \%$ for the next 8 years from 2010 onwards (see Table 5).

Table 5. Change of the NDVI density classes from 1990 to 2018

\begin{tabular}{|c|c|c|c|c|c|c|c|c|c|c|c|c|c|c|c|c|}
\hline \multirow{2}{*}{$\begin{array}{l}\text { NDVI } \\
\text { density } \\
\text { classes }\end{array}$} & \multicolumn{2}{|c|}{1990} & \multicolumn{2}{|c|}{1992} & \multicolumn{2}{|c|}{1994} & \multicolumn{2}{|c|}{1996} & \multicolumn{2}{|c|}{1998} & \multicolumn{2}{|c|}{2000} & \multicolumn{2}{|c|}{2002} & \multicolumn{2}{|c|}{2004} \\
\hline & Ha & $\%$ & Ha & $\%$ & Ha & $\%$ & Ha & $\%$ & Ha & $\%$ & Ha & $\%$ & Ha & $\%$ & Ha & $\%$ \\
\hline $\mathrm{H}$ & \begin{tabular}{|l|}
17407 \\
\end{tabular} & 31 & 13476 & 24 & 16845 & 30 & 15161 & 27 & 17968 & 32 & 15161 & 27 & 16284 & 29 & 12353 & 22 \\
\hline M & 22 & 40 & 29198 & 52 & 6498 & 65 & 263 & 47 & 37621 & 67 & 21 & 54 & 13476 & 24 & 83 & 42 \\
\hline \multirow[t]{3}{*}{$\mathrm{L}$} & 16283 & 29 & 13476 & 24 & 2807 & 5 & 14599 & 26 & 561 & 1 & 10668 & 19 & 26390 & 47 & 20214 & 6 \\
\hline & \multicolumn{2}{|c|}{2006} & \multicolumn{2}{|c|}{2008} & \multicolumn{2}{|c|}{2010} & \multicolumn{2}{|c|}{2012} & \multicolumn{2}{|c|}{2014} & \multicolumn{2}{|c|}{2016} & \multicolumn{2}{|c|}{2018} & & \\
\hline & Ha & $\%$ & Ha & $\%$ & $\mathrm{Ha}$ & $\%$ & $\mathrm{Ha}$ & $\%$ & Ha & $\%$ & $\mathrm{Ha}$ & $\%$ & Ha & $\%$ & & \\
\hline $\mathrm{H}$ & 11792 & 21 & 11230 & 20 & 5161 & 27 & 15722 & 28 & 12915 & 23 & 11230 & 20 & 14599 & 26 & & \\
\hline M & 2975 & 53 & 28637 & 51 & 23021 & 41 & 23583 & 42 & 29198 & 52 & 16845 & 30 & 25829 & 46 & & \\
\hline $\mathrm{L}$ & 14599 & 26 & 16283 & 29 & 17968 & 32 & 16845 & 30 & 14037 & 25 & 28075 & 50 & 15722 & 28 & & \\
\hline
\end{tabular}


In other words, the higher the value of index, indicated the healthier the vegetation would be. Therefore, the value constantly changing due to the majority of vegetation classes are subjected to transform to open space and built-up classes. The pattern of vegetation classes derived from NDVI density (see Fig. 4) were predominantly the main land use class in year 1990 to 1994. Beginning 1996 onwards, patches of other classes spread across Sepang starting to gradually increase year by year. This was interpreted as an encroachment and an environmental degradation of forest, farm and cropland and further reducing agricultural productive land. The encroachment of these land uses, the environmental degradation and reduced in agricultural productivities are among the characteristic of urban sprawl defined earlier in this study.
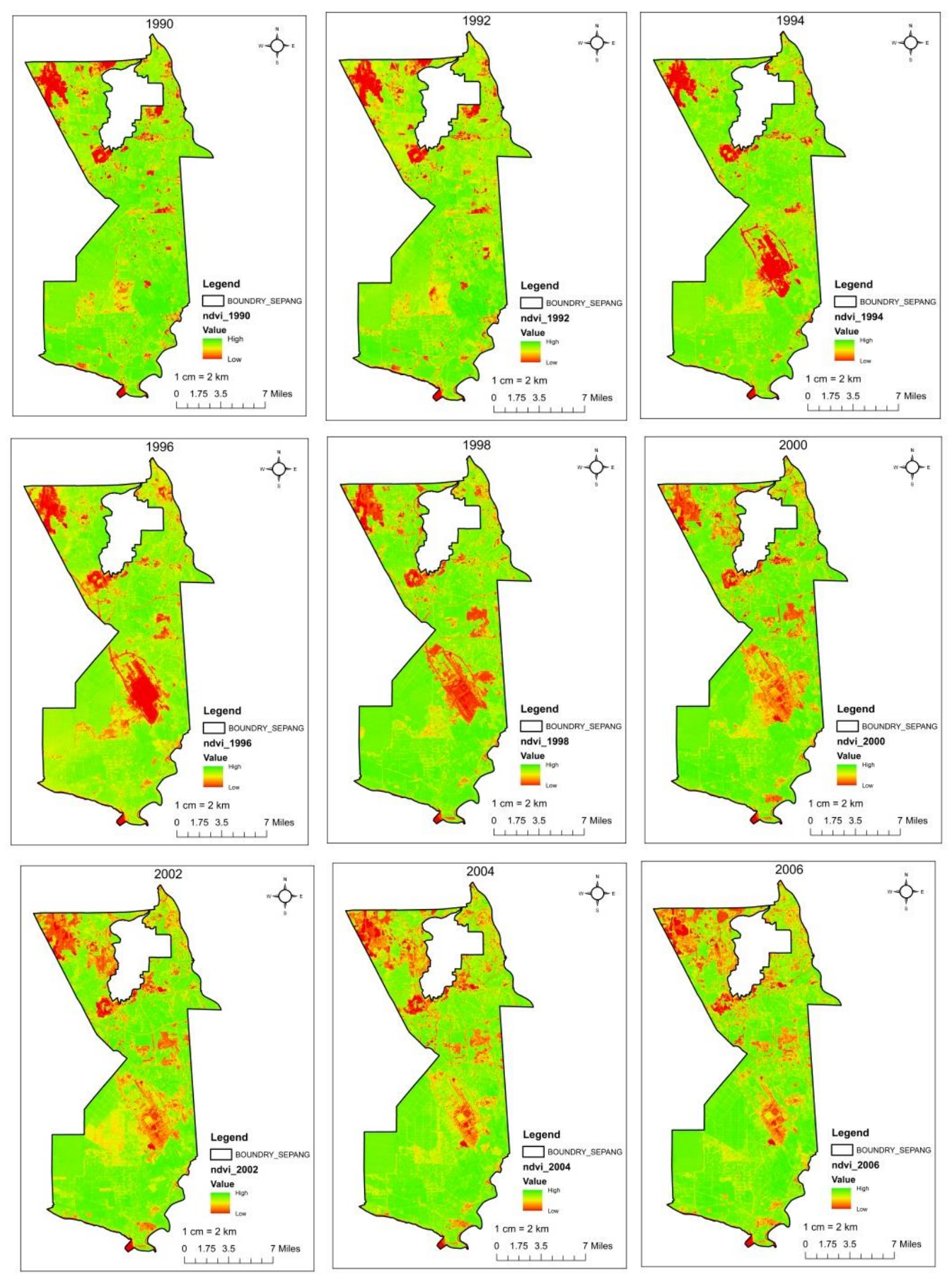

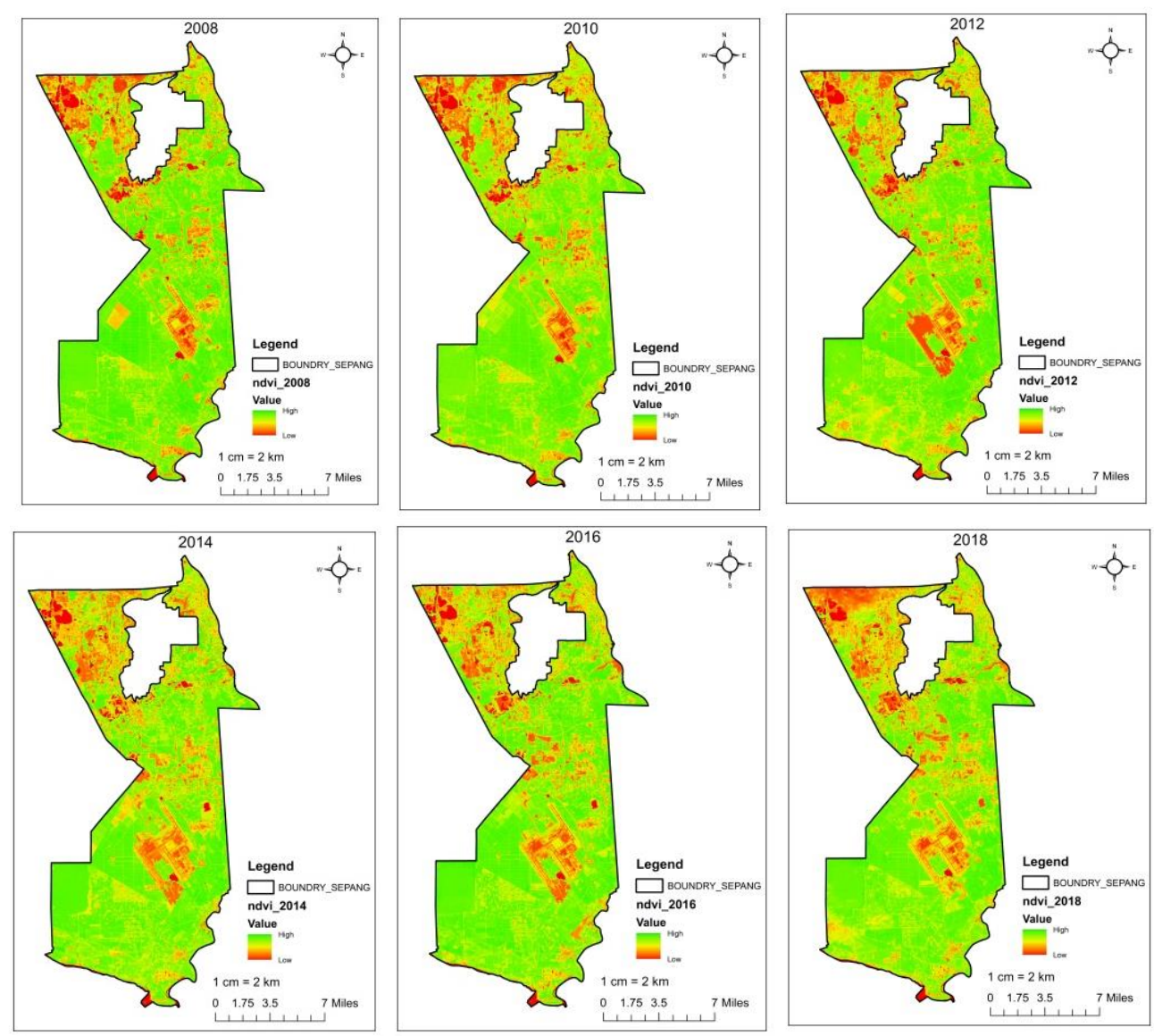

Figure 4. The NDVI density from 1990 to 2018 in Sepang district

A Normalized Difference Built-up Index (NDBI) is an arithmetic manipulation of NDVI except it is used for mapping built-up areas. The result of changes of index of very-high and high of NDBI density classes for 25 years indicated inconsistent of ups and downs of built-up classes. In contrarily, the result of changes of index of mediumand-low of NDBI indicated a consistent decreased throughput the longitudinal study. This is due to the fact that the highly demand for development on land use purposes will eventually cause an increasing in building index and reducing in vegetation index (Ewing and Hamidi, 2014). The pattern of built-up classes derived from NDBI density (see Fig. 5) was not the primary land use in early years. However, as early as the beginning of the longitudinal study, the built-up classes were already shown a sign of leapfrog, low density and scattered with polycentric development. Increased in built-up classes are necessary result in increase of impervious surface which effect water quality and increased of runoff water. By interpretation, Sepang has no specific urban growth boundary. Sepang was also part of Greater Kuala Lumpur with greater number of populations to reside in suburban areas. To add to the scenario, Putrajaya was rapidly growing at beginning of mid-1990s and continuously to do so, while Cyberjaya which also located within Sepang was the special economic corridor. Thus, Sepang was critically sprawled; backed with all the sprawl pattern - leapfrog, low density and scattered development; without any urban growth boundary; formed an urban environmental degradation, become the overpopulated suburban living for Putrajaya and Cyberjaya; and houses mass population for Greater Kuala Lumpur. 

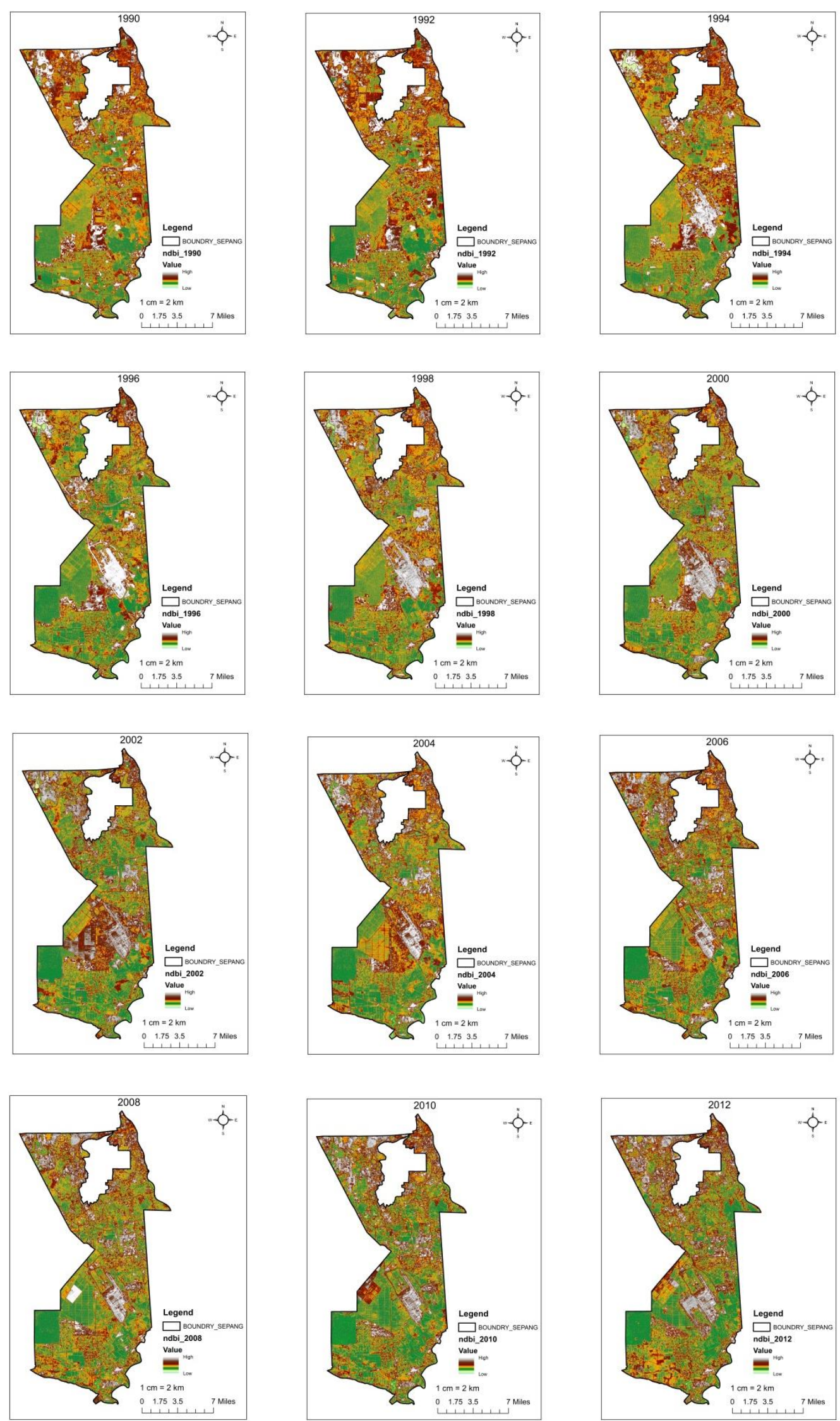

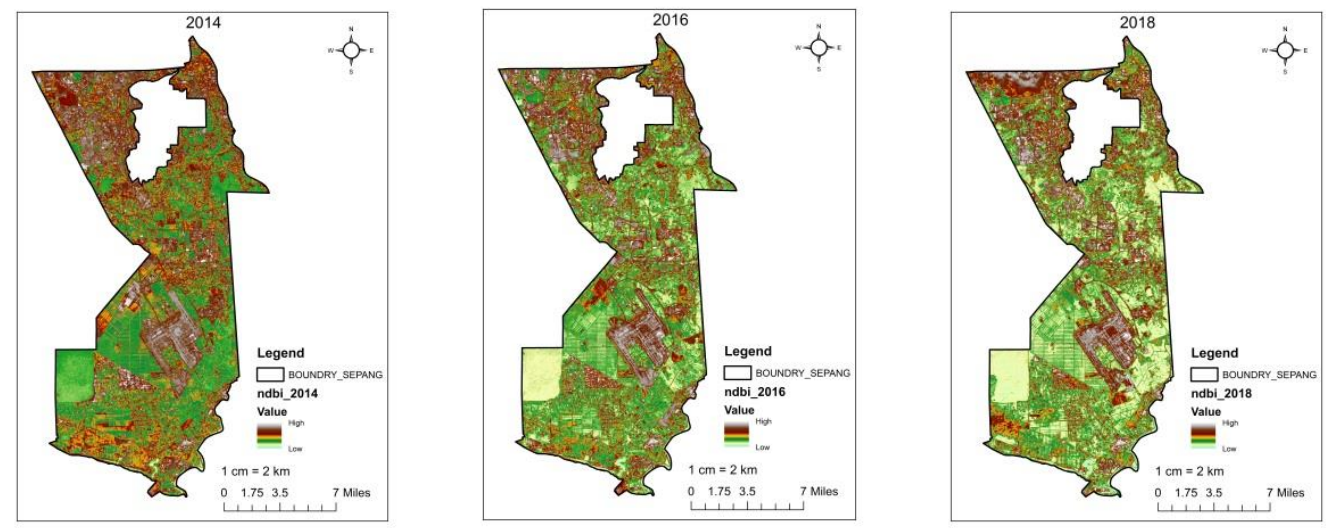

Figure 5. The NDBI density from 1990 to 2018 in Sepang district

\section{Conclusion}

Urbanization and rapid population growth are a major cause of land use changes and land conversions. It is essential in change detection to determine what type of land classes has change and the rate of change. Analyzing the spatial change with temporal aspects of urban growth can contribute to an effective planning and mitigate urban sprawl. Through this study, the urban expansion of Sepang over different period using time-series LULC and NDVI variation was achieved. The classification was able to clearly distinguished built-up area, vegetation area, water bodies, and open space. Land use land cover change detection showed an increased percentage of built-up area and open space, while reduce vegetation area. Only waterbodies had not shown any significant change. An NDVI quantified a steady declined of vegetation classes. The pattern of vegetation derived from NDVI density showed an encroachment and an environmental degradation of forest, farm and cropland and further reducing agricultural productive land. This is urban sprawl by definition. On the contrary, NDBI indicated inconsistent of ups and downs of built-up classes. However, the pattern of vegetation derived from NDBI density indicated urban sprawl patterns, urban sprawl characteristics and are associated with urban sprawl causes. Thus, the study proved urbanization and rapid population growth has caused urban sprawl to Sepang.

\section{REFERENCES}

[1] Abdullah, J. (2012): City competitiveness and urban sprawl: their implications to socioeconomic and cultural life in Malaysian cities. - Procedia-Social and Behavioral Sciences 50: 20-29.

[2] Barnes, K. B., Morgan III, J. M., Roberge, M. C., Lowe, S. (2001): Sprawl Development. Its Patterns, Consequences and Measurement. A white paper. - Towson University, Maryland.

[3] Behera, D. M., Borate, S. N., Panda, S. N., Behera, P. R., Roy, P. S. (2012): Modelling and analyzing the watershed dynamics using Cellular Automata (CA)-Markov model-A geo-information based approach. - Journal of Earth System Science 121(4): 1011-1024.

[4] Burchell, R. W., Lowenstein, G., Dolphin, W. R., Galley, C. C., Downs, A., Seskin, S., Gray Still, K., Moore, T. (2002): Costs of Sprawl-2000. Transportation Cooperative Research Program, Report 74. - National Academic Press, Washington, DC. 
[5] Bussauw, K. (2012): Challenges, threats and opportunities in post-conflict urbandevelopment in Kosovo. - Habitat International 36: 143-151.

[6] El Garouani, A., Mulla, D. J., El Garouani, S., Knight, J. (2017): Analysis of urban growth and sprawl from remote sensing data: Case of Fez, Morocco. - International Journal of Sustainable Built Environment 6(1): 160-169.

[7] El-Kawy, O. A., Rød, J. K., Ismail, H. A., Suliman, A. S. (2011): Land use and land cover change detection in the western Nile delta of Egypt using remote sensing data. Applied Geography 31(2): 483-494.

[8] Ewing, R., Hamidi, S. (2014): Measuring urban sprawl and validating sprawl measures. Technical Report Prepared for the National Cancer Institute, National Institutes of Health, the Ford Foundation, and Smart Growth America. - Smart Growth America, Washington, DC.

[9] Halmy, M. W. A., Gessler, P. E., Hicke, J. A., Salem, B. B. (2015): Land use/land cover change detection and prediction in the north-western coastal desert of Egypt using Markov-CA. - Applied Geography 63: 101-112.

[10] Herold, M., Goldstein, N. C., Clarke, K. C. (2003): The spatiotemporal form of urban growth: measurement, analysis and modeling. - Remote Sensing of Environment 86(3): 286-302.

[11] Hua, A. K., Ping, O. W. (2018): The influence of land-use/land-cover changes on land surface temperature: a case study of Kuala Lumpur metropolitan city. - European Journal of Remote Sensing 51(1): 1049-1069.

[12] Hua, A. K. (2017a): Application of Ca-Markov model and land use/land cover changes in Malacca River Watershed, Malaysia. - Applied Ecology and Environmental Research 15(4): 605-622.

[13] Hua, A. K. (2017b): Land use land cover changes in detection of water quality: a study based on remote sensing and multivariate statistics. - Journal of Environmental and Public Health. https://doi.org/10.1155/2017/7515130.

[14] Hua, A. K. (2018): SPATIAL-temporal analysis of pattern changes and prediction in Penang Island, Malaysia using LULC and CA-Markov model. - Applied Ecology and Environmental Research 16(4): 4619-4635.

[15] Lu, D., Mausel, P., Brondizio, E., Moran, E. (2004): Change detection techniques. International Journal of Remote Sensing 25(12): 2365-2401.

[16] Mahmud, A., Achide, A. S. (2012): Analysis of land use/land cover changes to monitor urban sprawl in Keffi-Nigeria. - Environmental Research Journal 6(2): 129-134.

[17] Mohd Noor, N., Alias, A., Mazlan, H., Zainora, M. A. (2012): Managing Urban Land In Developing Countries Using GIS And Remote Sensing: Towards Resilient Cities. Department of Urban and Regional Planning, IIUM, Gombak, Malaysia.

[18] Muller, D., Zeller, M. (2002): Land use dynamics in the central highlands of Vietnam: a spatial model combining village survey data with satellite imagery interpretation. Agricultural Economics 27(3): 333-354.

[19] Noor, N. M., Rosni, N. A. (2013): Determination of spatial factors in measuring urban sprawl in Kuantan using remote sensing and GIS. - Procedia-Social and Behavioral Sciences 85: 502-512.

[20] Nuissl, H., Rink, D. (2005): The "Production" of urban sprawl in Eastern Germany as a phenomenon of post-socialist transformation. - Cities 22: 123-134.

[21] Peiser, R. B. (2001): Decomposing urban sprawl. - Town Planning Review 72(3): 275298.

[22] Pontius, G. R., Malanson, J. (2005): Comparison of the structure and accuracy of two land change models. - International Journal of Geographical Information Science 19(2): 243-265.

[23] Pontius Jr, R. G., Millones, M. (2011): Death to Kappa: birth of quantity disagreement and allocation disagreement for accuracy assessment. - International Journal of Remote Sensing 32(15): 4407-4429. 
[24] Squires, G. D. (Ed.) (2002): Urban Sprawl: Causes, Consequences and Policy Responses. - The Urban Institute Press, Washington, DC.

[25] Statistical Department of Malaysia (2015): Population and Housing Census 2015. Department of Statistic Malaysia, Putrajaya.

[26] Sepang Municipal Council (2016). Sepang Local Plan 2020 (Ammendment 1). Retrieved from http://www.mpsepang.gov.my/en/main

[27] Statistical Department of Malaysia (1992): Population and Housing Census 1991. Department of Statistic Malaysia, Putrajaya.

[28] Stefanov, W. L., Ramsey, M. S., Christensen, P. R. (2001): Monitoring urban land cover change: An expert system approach to land cover classification of semiarid to arid urban centers. - Remote Sensing of Environment 77(2): 173-185.

[29] Tan, K. C., San Lim, H., MatJafri, M. Z., Abdullah, K. (2010): Landsat data to evaluate urban expansion and determine land use/land cover changes in Penang Island, Malaysia. - Environmental Earth Sciences 60(7): 1509-1521.

[30] Tehrany, M. S., Pradhan, B., Jebur, M. N. (2013): Remote sensing data reveals ecoenvironmental changes in urban areas of Klang Valley, Malaysia: contribution from object based analysis. - Journal of the Indian Society of Remote Sensing 41(4): 981-991.

[31] Weng, Q. (2002): Land use change analysis in the Zhujiang Delta of China using satellite remote sensing, GIS and stochastic modelling. - Journal of Environmental Management 64(3): 273-284.

[32] Weng, Q. H. (2010): Remote Sensing and GIS Integration. - McGraw-Hill, New York.

[33] Wilson, E. H., Hurd, J. D., Civco, D. L., Prisloe, M. P., Arnold, C. (2003): Development of a geospatial model to quantify, describe and map urban growth. - Remote Sensing of Environment 86(3): 275-285.

[34] Yue, M.-Y. (2011): Rethinking Asian cities and urbanization: four transformations in four decades. - Asian Geographer 28(1): 65-83. 